Endoglin (CD105) is an accessory receptor of transforming growth factor B. The highest synthesis, as well as expression, of endoglin has been found in vascular endothelial cells. The involvement of endoglin in angiogenesis and in angiogenesis-dependent processes has been observed.

Endoglin promotes angiogenesis not only by activation of vascular endothelial cell proliferation but also by induction of the antiapoptotic pathway in hypoxic endothelial cells.

The potential application of endoglin as a tumour angiogenesis marker, useful for cancer diagnostics and clinical application, is anticipated. Endoglin expression may be useful as an indicator of disease progression and helpful for estimation of recurrence and metastasis risk.

Key words: endoglin (CD105), vascular endothelial cells, tumor angiogenesis.

\section{Endoglin - a marker of vascular endothelial cell proliferation in cancer}

\section{Ewa Kopczyńska', Roman Makarewicz²}

\begin{abstract}
${ }^{1}$ Chair and Department of Pathobiochemistry and Clinical Chemistry, Ludwik Rydygier Collegium Medicum in Bydgoszcz, Nicolaus Copernicus University in Toruń, Poland ${ }^{2}$ Chair and Clinic of Oncology and Brachytherapy, Ludwik Rydygier Collegium Medicum in Bydgoszcz, Nicolaus Copernicus University in Toruń, Poland
\end{abstract}

\section{Introduction}

Endoglin is an accessory receptor of transforming growth factor $\beta$ (TGF- $\beta$ ). This glycoprotein does not carry the TGF- $\beta$ signal into the cell. Its essential role is modulation of signal transduction after ligand binding to type I re-

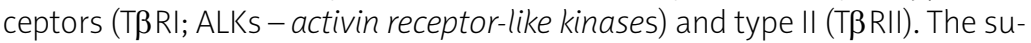
perfamily of transforming growth factors consists of TGF- $\beta$ isoforms (e.g. $\beta 1$, $\beta 2, \beta 3)$, activins and bone morphogenetic proteins (BMPs) [1].

\section{Transforming growth factor $\beta$}

Transforming growth factor $\beta$ is a regulator of proliferation, migration and survival of endothelial and smooth muscle cells. It participates in the maintenance of vascular homeostasis [2]. Transforming growth factor $\beta$ exerts its biological effects through interaction with receptor complexes of transmembrane serine/threonine kinases. Ligand binding to T $\beta$ RII causes receptors I and II to associate as interdependent components of a heteromeric complex: $T \beta R \mathrm{R}$ requires T $\beta$ RII to bind TGF- $\beta$, and T $\beta$ RII requires T $\beta R$ I for signal transduction [3]. Then, the phosphorylated T $\beta R$ I activates specific effectors, called Smads [4]. In endothelial cells that express type I receptors, both ALK1 and ALK5, signal transduction of TGF- $\beta$ is mediated by two different pathways, respectively Smad 1/5/8 and Smad 2/3. Complexes of the above Smads with Smad 4 translocate into the nucleus and modulate gene expression [2].

Transforming growth factor $\beta$ exerts bifunctional effects on endothelial cells in vitro; it can both stimulate (low doses) and inhibit (high doses) the proliferation and migration of endothelial cells and extracellular matrix formation [2]. The ratio between ALK 5 and ALK1 activation by TGF- $\beta$ in the endothelium eventually determines whether the endothelium is stimulated or remains quiescent [2]. The activation of the ALK1-Smad 1/5/8 pathway increases proliferation and migration of endothelial cells and induces the expression of pro-angiogenic genes (e.g. Id1, endoglin). On the other hand, the activation of the ALK5-Smad2/3 pathway results in inhibition of proliferation and migration of endothelial cells and activation of maturation-specific genes (e.g. fibronectin, plasminogen activator inhibitor-1). The ALK5 signalling pathway promotes recruitment and differentiation of peri-endothelial cells. In quiescent endothelium ALK5 is the dominating receptor; on the other hand, in angiogenesis ALK1 is activated [2].

\section{Structure of endoglin}

Endoglin (CD105 - cluster of differentiation 105) is a type I homodimeric cell membrane protein of $180 \mathrm{kDa}$, and it is composed of two disulfide-linked subunits. It has an extracellular domain consisting of 561 amino acids, a hydrophobic transmembrane domain of 25 aa, and a residue cytoplasmic tail of 47 aa [5].

The presence of tripeptide arginine-glycine-aspartic acid (RGD), characteristic for proteins of extracellular matrix (fibronectin, type I collagen, etc.), suggests 
the role of endoglin as a ligand for integrins and other receptors binding $\operatorname{RGD}[5,6]$.

There are four potential $\mathrm{N}$-linked glycosylation sites and rich in serine and threonine O-glycan domain, which may be phosphorylated in the N-terminal domain [5].

Endoglin is expressed as two isoforms, designated long (L-CD105) and short (S-CD105), based on the length of the cytoplasmic domain [7].

\section{Cellular endoglin distribution}

Endoglin is primarily expressed on endothelial cells, especially activated. In addition, it is found on the surface of several other cell types, e.g. hematopoietic progenitor cells, bone marrow stromal fibroblasts, activated monocytes, differentiated macrophages, melanocytes, and syncytiotrophoblasts of placenta [8].

\section{Modulation of endoglin expression}

Different environmental factors and cytokines involved in angiogenesis modulate endoglin expression. Hypoxia and TGF- $\beta$ are the two main factors which cooperate to induce endoglin expression either at the transcriptional or the protein level $[9,10]$. Hypoxic regulation of endoglin expression involves kinases (p38 mitogen-activated protein kinase MAPK, and Jun amino-terminal kinase - JNK) and transcriptional factors (HIF-1 - hypoxia-inducible factor-1 and Sp1) [10]. However, induction by TGF- $\beta$ involves Smad3 protein and Sp1 [11].

Hypoxia alone moderately stimulates endoglin transcription, in addition with TGF- $\beta$, leading to marked stimulation. Endoglin transcription is sustained by Sp1, whereas the TGF- $\beta$ signalling pathway is mediated by Smad proteins, and hypoxia by HIF-1. The existence of a multiprotein complex (Sp1/Smad3/HIF-1) on the endoglin promoter suggests the cooperation in induction of endoglin synthesis between TGF- $\beta$ and hypoxia [9]

Injury-induced KLF6 and pre-existing Sp1 may cooperate in regulating the expression of endoglin in vascular repair [12].

\section{Interaction of endoglin with ligands and other receptors}

Endoglin belongs to the family of TGF- $\beta$ receptors. It does not bind TGF- $\beta$ isoforms on its own but requires the presence of specific receptors. It forms complexes with type I and II TGF- $\beta$ receptors, through both extracellular and cytoplasmic domains, independently of ligands presence and kinase activation state [13].

It binds many TGF- $\beta$ isoforms, especially TGF- $\beta 1$ and TGF- $\beta 3$, but also activin A, BMP-2 and BMP-7. High affinity of endoglin to TGF- $\beta 1$ and moderate to TGF- $\beta 3$ results from the binding of this accessory receptor only with ligands which bind to T $\beta$ RII. It suggests the role of endoglin in the dynamics of type I/II receptors and ligand interactions [14].

\section{Regulation of endoglin activity}

Rich in serine and threonine, the cytoplasmic domain of endoglin is constitutively phosphorylated and plays a role in the regulation of dimerisation and signalling. Both T $T \beta R$ and T $\beta R$ II phosphorylate the cytoplasmic domain of endoglin, and then T $\beta R \mathrm{R}$, but not T $\beta$ RII, dissociates from the complex [15]. The consequence of T $\beta R I$ and T $\beta R$ II interactions with endoglin is an increased level of phosphorylated Smad2 protein, and it suggests that this accessory receptor modulates the TGF- $\beta$-dependent cellular response [16].

TGF- $\beta$ and protein kinase $\mathrm{C}$ inhibitor $\mathrm{H}-7$ reduce the level of endoglin phosphorylation [17].

\section{Functional activity of endoglin}

The mechanism by which endoglin modulates TGF- $\beta$-induced signal transduction is not clear. Endoglin both enhances and inhibits ALK5 and ALK1 receptor signalling. It enhances ALK5/Smad2 signalling [15], and inhibits ALK5/Smad3 [18]. In addition, endoglin enhances TGF- $\beta$ /ALK1 signalling and endothelial cell proliferation, but simultaneously it indirectly inhibits ALK5 [19]. The balance of ALK1 and ALK5 signalling is crucial for the regulation of endothelial cell proliferation [19].

In hypoxic endothelial cells, endoglin prevents apoptosis; this accessory receptor is an antiapoptotic factor [10].

Endoglin inhibits the migration of several types of cells (e.g. smooth muscle cells, fibroblasts) and decreases focal adhesion [20]. The following endoglin-dependent processes are mediated by the cytoplasmic domain of endoglin [20]: (a) inhibition of cell migration, (b) reduction of focal adhesionassociated p130cas/Crkll protein levels, (c) tyrosine phosphorylation of p130cas, and (d) focal adhesion-associated endoglin levels.

The cytoplasmic domain of endoglin binds the LIM domain of zyxin-related protein-1 (ZRP-1) and zyxin. This may suggest a regulatory role for endoglin in the actin cytoskeletal organization [21].

Endoglin is a regulator of nitric oxide-dependent vasodilatation. Its overexpression in cultured endothelial cells increases the level of nitric oxide synthase [22].

\section{The role of endoglin in angiogenesis}

Even if the functional role of endoglin is not fully understood, several findings suggest its involvement in angiogenesis and vascular development, and in maintenance of vessel wall integrity:

1. Endoglin is overexpressed on proliferating endothelial cells in tissues undergoing active angiogenesis, such as regenerating and inflamed tissues or tumours [23].

2. The inhibition of endoglin expression not only enhances the ability of TGF- $\beta$ to suppress growth and migration of endothelial cells but also enhances apoptosis induced by hypoxia and TGF- $\beta$ [24].

3. The presence of RGD tripeptide, a key recognition structure in cellular adhesion, suggests a critical role of endoglin in the binding of endothelial cells to integrins and/or other $\mathrm{RGD}$ receptors [5].

4. Endoglin modulates the expression of different components of the extracellular matrix including fibronectin, collagen, PAI-1 and lumican [25].

5. Endoglin gene mutations are associated with hereditary haemorrhagic telangiectasia type 1 , a disorder characterized by multisystemic vascular dysplasia and recurrent haemorrhage [26]. 


\section{Endoglin expression in cancer}

The strong overexpression of endoglin in the endothelium of various tumour tissues compared with that in normal tissues may be evidence of its role in angiogenesis [27]. In solid malignancies, endoglin is almost exclusively expressed on endothelial cells of both peri- and intra-tumoural blood vessels and on tumour stromal components. It is especially expressed in small and immature tumour vessels. Rarely, endoglin expression has been found in the cytoplasm of neoplastic cells [28].

Both mRNA and protein expression is significantly increased in proliferating endothelial cells. A correlation was found between levels of endoglin expression and endothelial cell proliferation, and microvessel density, as well as with markers of cell proliferation (i.e. cyclin A and Ki-67) in tumour endothelia [23].

\section{The diagnostic significance of endoglin in malignant disease}

Endoglin is overexpressed in endothelia of vessels in several human solid malignancies, e.g. glioblastoma [29], oral and oropharyngeal carcinoma [30], laryngeal carcinoma [31], lung cancer (ca) [32], breast ca [33], ovarian ca [34], cervical ca [35], endometrial ca [36, 37], prostate ca [38], colorectal ca [39], gastric ca [40], and hepatocellular ca [41]. Endoglin expression is a better prognostic marker than other traditional vessels markers, such as CD31 and CD34 [29, 32, 36, 38, 41]. In various tumours endoglin overexpression was associated with lower patient survival rates, presence of node metastases and distant metastatic disease [29-34, 37-41]. Endoglin has been examined as a target of antiangiogenic and antitumor therapy $[25,28]$.

Increased levels of soluble form of endoglin in blood plas$\mathrm{ma}$ /serum in various solid tumours have been noted, e.g. prostate ca [42], breast ca [43], colorectal ca [44], and liver ca [45]. The serum level of endoglin was significantly elevated in patients with metastatic cancers $[43,44]$. However, chemotherapy suppressed its serum levels in cancer patients [44]. The results of these studies suggest that the concentration of circulating endoglin may be helpful in prediction of metastases and in estimation of therapy effects.

\section{References}

1. Kingsley DM. The TGF-beta superfamily: new members, new receptors, and new genetic tests of function in different organisms. Genes Development 1994; 8: 133-46

2. Bertolino P, Deckers M, Lebrin F, ten Dijke P. Transforming growth factor-beta signal transduction in angiogenesis and vascular disorders. Chest 2005; 128: 585-90.

3. Wrana JL, Attisano L, Carcamo J, Zentella A, Doody J, Laiho M, Wang XF, Massague J. TGF beta signals through a heteromeric protein kinase receptor complex. Cell 1992; 71: 1003-14.

4. Heldin C, Miyazono K, ten Dijke P. TGF-beta signalling from cell membrane to nucleus through SMAD proteins. Nature 1997; 390: 465-71.

5. Gougos A, Letarte M. Primary structure of endoglin, an RGD-containing glycoprotein of human endothelial cells. J Biol Chem 1990; 265: 8361-4.

6. Lastres P, Bellon T, Cabańas C, Sanchez-Madrid F, Acevedo A, Gougos A, Letarte M, Bernabeu C. Regulated expression on human macrophages of endoglin, an Arg-Gly-Asp-containing surface antigen. Eur J Immunol 1992; 22: 393-7.
7. Bellón T, Corbí A, Lastres P, et al. Identification and expression of two forms of the human transforming growth factor-beta-binding protein endoglin with distinct cytoplasmic regions. Eur J Immunol 1993; 23: $2340-5$.

8. Dallas NA, Samuel S, Xia L, Fan F, Gray MJ, Lim SJ, Ellis LM. Endoglin (CD105): A marker of tumor vasculature and potential target for therapy. Clin Cancer Res 2008; 14: 1931-7.

9. Sánchez-Elsner T, Botella LM, Velasco B, Langa C, Bernabéu C. Endoglin expression is regulated by transcriptional cooperation between the hypoxia and transforming growth factor-beta pathways. J Biol Chem 2002; 277: 43799-808.

10. Li C, Issa R, Kumar P, Hampson IN, Lopez-Novoa JM, Barnabeu C, Kumar S. CD105 prevents apoptosis in hypoxic endothelial cells. J Cell Sci 2003; 116: 2677-85.

11. Botella LM, Sánchez-Elsner T, Rius C, Corbí A, Bernabéu C. Identification of a critical Sp1 site within the endoglin promoter and its involvement in the transforming growth factor-beta stimulation. J Biol Chem 2001; 276: 34486-34494.

12. Botella LM, Sánchez-Elsner T, Sanz-Rodriguez F, et al. Transcriptional activation of endoglin and transforming growth factor-beta signaling components by cooperative interaction between Sp1 and KLF6: their potential role in the response to vascular injury. Blood 2002; 100: 4001-10.

13. Yamashita H, Ichijo H, Grimsby S, Morén A, ten Dijke P, Miyazono K. Endoglin forms a heteromeric complex with the signaling receptors for transforming growth factor-beta. J Biol Chem 1994; 269: 1995-2001.

14. Barbara NP, Wrana JL, Letarte M. Endoglin is an accessory protein that interacts with the signaling receptor complex of multiple members of the transforming growth factor-beta superfamily. J Biol Chem 1999; 274: 584-94.

15. Guerrero-Esteo M, Sanchez-Elsner T, Letamendia A, Bernabeu C. Extracellular and cytoplasmic domains of endoglin interact with the transforming growth factor-beta receptors I and II. J Biol Chem 2002; 277: 29197-209.

16. Lastres P, Letamendía A, Zhang H, et al. Endoglin modulates cellular responses to TGF-beta 1. J Cell Biol 1996; 133: 1109-21.

17. Lastres P, Martín-Perez J, Langa C, Bernabéu C. Phosphorylation of the human-transforming-growth-factor-beta-binding protein endoglin. Biochem J 1994; 301: 765-8.

18. Guo B, Slevin M, Li C, Parameshwar S, Liu D, Kumar P. CD105 inhibits transforming growth factor beta Smad3 signalling. Anticancer Res 2004; 24: 1337-45.

19. Lebrin F, Goumans M-J, Jonker L et al. Endoglin promotes endothelial cell proliferation and TGF-beta/ALK1 signal transduction. EMBO J 2004; 23: 4018-4028.

20. Conley BA, Koleva R, Smith JD, Kacer D, Zhang D, Bernabéu C, Vary CP. Endoglin controls cell migration and composition of focal adhesions. J Biol Chem 2004; 279: 27440-9

21. Sanz-Rodriguez F, Guerrero-Esteo M, Botella LM, Banville D, Vary CP, Bernabéu C. Endoglin regulates cytoskeletal organization through binding to ZRP-1, a member of the Lim family of proteins. J Biol Chem 2004; 279: 32858-68

22. Jerkic M, Rivas-Elena JV, Prieto $M$, et al. Endoglin regulates nitric oxide-dependent vasodilatation. FASEB J 2004; 18: 609-11.

23. Miller DW, Graulich W, Karges B et al. Elevated expression of endoglin, a component of the TGF- $\beta$ receptor complex, correlates with proliferation of tumor endothelial cells. Int J Cancer 1999; 81: 568-72.

24. Li C, Hampson IN, Hampson L, Kumar P, Bernabeu C, Kumar S. CD105 antagonizes the inhibitory signaling of transforming growth factor 1 on human vascular endothelial cells. FASEB J 1999; 14: 55-64.

25. Fonsatti E, Maio M. Highlights on endoglin (CD105): from basic findings towards clinical applications in human cancer. J Translat Med 2004; 2: 18.

26. McAllister KA, Grogg KM, Johnson DW et al. Endoglin, a TGF-beta binding protein of endothelial cells, is the gene for hereditary haemorrhagic telangiectasia type 1. Nat Genet 1994; 8: 345-51.

27. Duff SE, Li CH, Garland JM, Kumar S. CD105 is important for angiogenesis: evidence and potential applications. FASEB J 2003; 17: 984-92.

28. Fonsatti E, Altomonte M, Nicotra MR, Natali PG, Maio M. Endoglin (CD105): a powerful therapeutic target on tumor-associated angiogenetic blood vessels. Oncogene 2003; 22: 6557-63. 
29. Behrem S, Zarkowić K, Eskinja N, Jonjić N. Endoglin is a better marker than CD31 in evaluation of angiogenesis in glioblastoma. Croat Med J 2005; 46: 417-22.

30. Marioni G, Marino F, Giacomelli L, Staffieri C, Mariuzzi ML, Violino E, De Filippis C. Endoglin expression is associated with poor oncologic outcome in oral and oropharyngeal carcinoma. Acta Otolaryngol 2006; 126: 633-9.

31. Marioni G, Giacomelli L, D’Alessandro E, Staffieri C, Guzzardo V, Staffieri A, Blandamura S. Laryngeal carcinoma recurrence rate and disease-free interval are related to CD105 expression but not to vascular endothelial growth factor 2 (Flk $1 / \mathrm{Kdr}$ ) expression. Anticancer Res 2008; 28: 551-7.

32. Tanaka F, Otake Z, Yanagihara $\mathrm{K}$ et al. Evaluation of angiogenesis in non-small cell lung cancer: comparison between anti-CD34 antibody and anti-CD105 antibody. Clin. Cancer Res 2001; 7: 3410-5.

33. Oxmann D, Held-Feindt J, Stark AM, Hattermann K, Yoneda T, Mentlein R. Endoglin expression in metastatic breast cancer cells enhances their invasive phenotype. Oncogene 2008; 27: 3567-75.

34. Taskiran C, Erdem O, Onan A et al. The prognostic value of endoglin (CD105) expression in ovarian carcinoma. Int J Gynecol Cancer 2006; 16: 1789-93.

35. Zijlmans HJ, Fleuren GJ, Hazelbag S, Sier CF, Dreef EJ, Kenter GG, Gorter A. Expression of endoglin (CD105) in cervical cancer. Br J Cancer 2009; 100: 1617-26.

36. Saad RS, Jasnosz KM, Tung MY, Silverman JF. Endoglin (CD105) expression in endometrial carcinoma. Int J Gynecol Pathol 2003; 22: 248-53.

37. Salvensen HB, Gulluoglu MG, Stefansson I, Akslen LA. Significance of CD105 expression for tumour angiogenesis and prognosis in endometrial carcinomas. APMIS 2003; 111: 1011-8.

38. El-Gohary Y, Silverman JF, Olson PR, Liu YL, Cohen JK, Miller R, Saad RS. Endoglin (CD105) and vascular endothelial growth factor as prognostic markers in prostatic adenocarcinoma. Am J Clin Pathol 2007; 127: 572-9.

39. Saad RS, Liu YL, Nathan G, Celebrezze J, Medich D, Silverman JF. Endoglin (CD105) and vascular endothelial growth factor as prognostic markers in colorectal cancer. Modern Pathology 2004; 17: 197-203.

40. Nikiteas NI, Tzanakis N, Theodoropoulos G et al. Vascular endothelial growth factor and endoglin (CD-105) in gastric cancer. Gastric Cancer 2007; 10: 12-7.

41. Yang L, Lu W, Huang G, Wang W. Correlation between CD105 expression and postoperative recurrence and metastasis of hepatocellular carcinoma. BMC Cancer 2006; 6: 110.

42. Karam JA, Svatek RS, Karakiewicz PI, Gallina A, Roehrborn CG, Slawin KM, Shariat SF. Use of preoperative plasma endoglin for prediction of lymph node metastasis in patients with clinically localized prostate cancer. Clin Cancer Res 2007; 14: 1418-22.

43. Li C, Guo B, Wilson PB, Stewart A, Byrne G, Bundred N, Kumar S. Plasma levels of soluble CD105 correlate with metastasis in patients with breast cancer. Int J Cancer 2000; 89: 122-6.

44. Takahashi N, Kawanishi-Tabata R, Haba A, Tabata M, Haruta Y, Tsai H, Seon BK. Association of serum endoglin with metastasis in patients with colorectal, breast, and other solid tumors, and suppressive effect of chemotherapy on the serum endoglin. Clin Cancer Res 2001; 7: 524-32.

45. Yagmur E, Rizk M, Stanzel S, Hellerbrand C, Lammert F, Trautwein C, Wasmuth HE, Gressner AM. Elevation of endoglin (CD105) concentrations in serum of patients with liver cirrhosis and carcinoma. Eur J Gastroenterol Hepatol 2007; 19: 755-61.

\section{Address for correspondence}

\section{Ewa Kopczyńska}

Katedra i Zakład Patobiochemii i Chemii Klinicznej

Collegium Medicum im. Ludwika Rydygiera

ul. Marii Skłodowskiej-Curie 9

85-094 Bydgoszcz

e-mail: kopczynska@cm.umk.p

Submitted: $\quad 4.06 .2009$

Accepted: $\quad 02.12 .2011$ 